\title{
Body temperature around induced estrus in dairy cows
}

\author{
V. S. Suthar, ${ }^{*}$ O. Burfeind, ${ }^{*}$ J. S. Patel, $†$ A. J. Dhami, $\neq$ and W. Heuwieser ${ }^{* 1}$ \\ ${ }^{*}$ Clinic of Animal Reproduction, Faculty of Veterinary Medicine, Freie Universität Berlin, Koenigsweg 65, 14163 Berlin, Germany \\ †Department of Agricultural Statistics, B. A. College of Agriculture, Anand Agricultural University, Anand-388110 (GUJARAT), India \\ $\ddagger D$ epartment of Animal Reproduction Gynaecology and Obstetrics, College of Veterinary Science, Anand Agricultural University, \\ Anand-388110 (GUJARAT), India
}

\section{ABSTRACT}

The overall objective of this study was to study the influence of induced estrus on body temperature, comparing 5 distinct intervals around induced estrus and to determine the diurnal pattern from $4 \pm 1 \mathrm{~d}$ before to 4 $\pm 1 \mathrm{~d}$ after induced estrus. Sixteen estrous cycles of 9 postpartum dairy cows were synchronized with 2 injections of $\mathrm{PGF}_{2 \alpha}, 10 \mathrm{~d}$ apart. After the second $\mathrm{PGF}_{2 \alpha}$ injection on d 10, temperature loggers were inserted into the vaginal cavity for a $12 \pm 1$-d period. Two days later, a third dose of $\mathrm{PGF}_{2 \alpha}$ was injected to induce estrus. After confirmation of a corpus luteum, loggers were removed on $\mathrm{d} 5 \pm 1$. Observation of estrus, rectal palpation, and ultrasound scanning to determine ovulation were carried out every $4 \pm 1 \mathrm{~h}$, beginning at $12 \mathrm{~h}$ after the third $\mathrm{PGF}_{2 \alpha}$ injection. Blood samples from the vena coccygea mediana were collected twice daily from d 11 to 12 and every $4 \pm 1 \mathrm{~h}$ after the third $\mathrm{PGF}_{2 \alpha}$ injection until ovulation. Vaginal temperature was recorded every $5 \mathrm{~min}$ and averaged to hourly means for the following 5 periods: 1) $48 \mathrm{~h}$ preceding the third $\mathrm{PGF}_{2 \alpha}$ injection, 2) from the third $\mathrm{PGF}_{2 \alpha}$ injection to first signs of estrus, 3) estrus to ovulation, 4) a 4-h interval in which ovulation occurred, and 5) a 96-h post-ovulation period. High body temperatures $\left(39.0 \pm 0.5^{\circ} \mathrm{C}\right)$ and low progesterone $(\mathrm{P} 4)$ concentrations $(<0.5 \mathrm{ng} / \mathrm{mL})$ were observed during estrus, whereas low body temperatures were observed from $\mathrm{PGF}_{2 \alpha}$ injection to estrus (38.6 \pm $0.3^{\circ} \mathrm{C}$ ) and around ovulation $\left(38.5 \pm 0.2^{\circ} \mathrm{C}\right)$, respectively. An association between body temperature and serum P4 concentrations did not exist. However, P4 concentrations on d 11 and 12 were high $(5.0 \pm 1.5 \mathrm{ng} /$ $\mathrm{mL})$ and decreased $(0.9 \pm 0.2 \mathrm{ng} / \mathrm{mL})$ after ovulation. Diurnal temperature rhythms were similar before and after estrus. Vaginal temperature before estrus (d 11 and 12$)$ was slightly $\left(0.1^{\circ} \mathrm{C}\right)$ higher compared with the post-ovulation period.

Received September 24, 2010.

Accepted February 1, 2011.

${ }^{1}$ Corresponding author: heuwieser.wolfgang@vetmed.fu-berlin.de
Key words: body temperature, rhythm, induced estrus, progesterone

\section{INTRODUCTION}

It is well known that body temperature in homeothermic animals shows biological variation. Circadian and estrous cycle rhythmicities have been demonstrated in dairy cattle considering a range of physiological and behavioral variables (Lewis and Newman, 1984; Kyle et al., 1998).

In humans, basal body temperature records are routinely used for contraceptive purposes as well as for the management of infertility (Martinez et al., 1992). Several researchers have reported an elevation of body temperature in cows during estrus, a decrease around ovulation, and a subsequent increase and decrease during mid-estrus and 2 to $3 \mathrm{~d}$ before estrus, respectively (Wrenn et al., 1958; Redden et al., 1993; Kyle et al., 1998).

The duration of the estrus-related increase of body temperature varied from 3 to $6.5 \mathrm{~h}$ (Clapper et al., 1990; Mosher et al., 1990; Redden et al., 1993) and the amplitude of the increase was up to $0.9 \pm 0.3^{\circ} \mathrm{C}$ (Kyle et al., 1998). The temperature rhythms during the estrous cycle have been measured by rectal (Wrenn et al., 1958) and vaginal thermometry (Clapper et al., 1990; Mosher et al., 1990; Redden et al., 1993) and were shown to be associated to LH surge and ovulation. Reports are also available which assumed that the higher body temperature during estrus is caused by increased physical activity (Lewis and Newman, 1984; Walton and King, 1986). Other studies suggested that the thermogenic effect of progesterone $(\mathbf{P} 4)$ secreted during the luteal phase contributed to the rise in body temperature (Wrenn et al., 1958; Kyle et al., 1998). A direct correlation, however, between body temperature and P4 concentrations did not exist (Lammoglia et al., 1997).

In the past, different technologies have been applied for continuously monitoring body temperature in cattle, including temperature boluses placed in the reticulum (Bewley et al., 2008) and rumen (Ipema et al., 
2008), implanting transmitters in the abdominal cavity (Brown-Brandl et al., 2005), implanting thermistors in the udder (Bitman et al., 1984; Lefcourt et al., 1999) and intravaginal radio-telemetry units (Clapper et al., 1990; Kyle et al., 1998). These approaches have provided important information on amplitude and rhythmicity of body temperature but did not account for variation related to different stages of the estrous cycle. Several studies used microprocessor controlled data loggers (Minilog-TX data logger, Vemco Ltd.; Shad Bay, NS, Canada) inserted into the vaginal cavity to continuously measure core temperature of dairy cows (Tucker et al., 2008; Kendall and Webster, 2009; Schütz et al., 2009). Most recently, our group has validated the use of these vaginal temperature loggers through comparisons with a water bath as a gold standard and with rectal temperatures as the cowside reference method (Vickers et al., 2010) and reported negligible differences between vaginal and rectal temperature for dairy cows.

When vaginal temperature was measured every 4 min for an entire estrous cycle via radiometric transmitters, the prediction of ovulation had a sensitivity of 80 to $87 \%$ and a false positive rate of 10 to $17 \%$ (Redden et al., 1993; Kyle et al., 1998). Two studies (Rajamahendran et al., 1989; Rajamahendran and Taylor, 1991) have reported vaginal and rectal temperatures during $\mathrm{PGF}_{2 \alpha^{-}}(\mathrm{n}=10)$ and $\mathrm{P} 4-(\mathrm{n}=8)$ induced estrus, using clinical thermometers in 4-h intervals. It is well known, however, that due to the diurnal rhythm, body temperature can fluctuate considerably within $4 \mathrm{~h}$. Only one study (Zartman et al., 1983) measured body temperature frequently using intravaginal radio-telemetry transmitters in 4 Holstein heifers with $\mathrm{PGF}_{2 \alpha}$-induced estrus but failed to demonstrate a temperature peak. A dearth of information exists on how synchronization of the estrous cycle affects body temperature rhythm, considering more frequent measurements.

The objectives of this study were to study body temperature during $\mathrm{PGF}_{2 \alpha}$-induced estrous cycles. Specifically, we set out 1 ) to evaluate the influence of induced estrus on body temperature, comparing 5 defined intervals relative to $\mathrm{PGF}_{2 \alpha}$ administration and induced estrus and 2) to determine the diurnal rhythm in body temperature in cyclic cows from $4( \pm 1)$ d before to 4 $( \pm 1)$ d after $\mathrm{PGF}_{2 \alpha}$-induced estrus.

\section{MATERIALS AND METHODS}

\section{Animals}

Between November 2009 and May 2010, 9 healthy, lactating, and cycling dairy cows $(275 \pm 100$, DIM; mean $\pm \mathrm{SD}$ ) were enrolled and housed in a tie stall barn with straw bedding at the Clinic of Animal Re- production, Freie Universität Berlin, Germany (latitude $52^{\circ} 25^{\prime} 37^{\prime \prime} \mathrm{N}$, longitude $13^{\circ} 14^{\prime} 14^{\prime \prime} \mathrm{E}$ ). Animals were fed twice daily with grass, silage, concentrate, and hay.

Ambient temperature and relative humidity $(\mathrm{RH})$ within the experimental pen were recorded hourly using a Tinytag Plus II logger (Gemini Loggers Ltd., Chichester, West Sussex, UK), which was secured at a beam $3 \mathrm{~m}$ from the ground. The temperature humidity index (THI) was calculated according to the equation reported by Kendall et al. (2008): THI $=(1.8 \times \mathrm{T}+$ $32)-[(0.55-0.0055 \times \mathrm{RH}) \times(1.8 \times \mathrm{T}-26)]$.

Ovarian status was assessed by ultrasonography with a linear scanner (Tringa Linear, Esaote Pie Medical, Maastricht, the Netherlands). After ultrasound-based diagnosis of a corpus luteum (CL) on one of the ovaries $0.5 \mathrm{mg}$ of Cloprostenol (PGF Veyx forte, Veyx-Pharma $\mathrm{GmbH}$, Schwarzenborn, Germany) was administered. This treatment was repeated $10 \mathrm{~d}$ later to synchronize estrus. Follicular development was monitored by ultrasound examinations twice daily (0800 and $1600 \mathrm{~h}$ ) for $10 \mathrm{~d}$ after the second $\mathrm{PGF}_{2 \alpha}$ treatment.

\section{Temperature Measurement}

Vaginal temperatures were measured at 5-min intervals with a microprocessor-controlled temperature logger (Minilog 8, Vemco Ltd., Halifax, Canada) attached to a modified vaginal controlled internal drug release $(\mathrm{CIDR})$ insert. Temperature loggers $($ size $=92 \mathrm{~mm} \times$ $20 \mathrm{~mm}$; weight $=40.5 \mathrm{~g})$ were inserted in the vaginal cavity for a $12( \pm 1)-d$ period $10 \mathrm{~d}$ after the second $\mathrm{PGF}_{2 \alpha}$ injection. Two days later a third $\mathrm{PGF}_{2 \alpha}$ was injected to induce estrus. Five $( \pm 1)$ days after confirmation of a CL loggers were removed (Figure 1).

\section{Estrus Detection}

Estrus observation through secondary signs of estrus (i.e., vaginal discharge, behavior changes), and rectal palpation were carried out every $4 \pm 1 \mathrm{~h}$ beginning at $12 \mathrm{~h}$ after the third $\mathrm{PGF}_{2 \alpha}$ injection. During the first ultrasound examination, each ovary was scanned in 3 layers to identify the largest follicle. The ovary displaying the largest follicle was scanned every $4 \pm 1$ $\mathrm{h}$ until ovulation. After ovulation, ultrasonography was conducted every other day to detect a developing CL for confirmation of a physiological cycle until d $5( \pm 1)$. The day of estrus was considered as d 0 .

\section{Blood Collection for Hormone Analysis}

Blood samples were obtained by puncture of the vena coccygea mediana using a Vacutainer system (Venoject II, Terumo Europe N.V., Leuven, Belgium). 


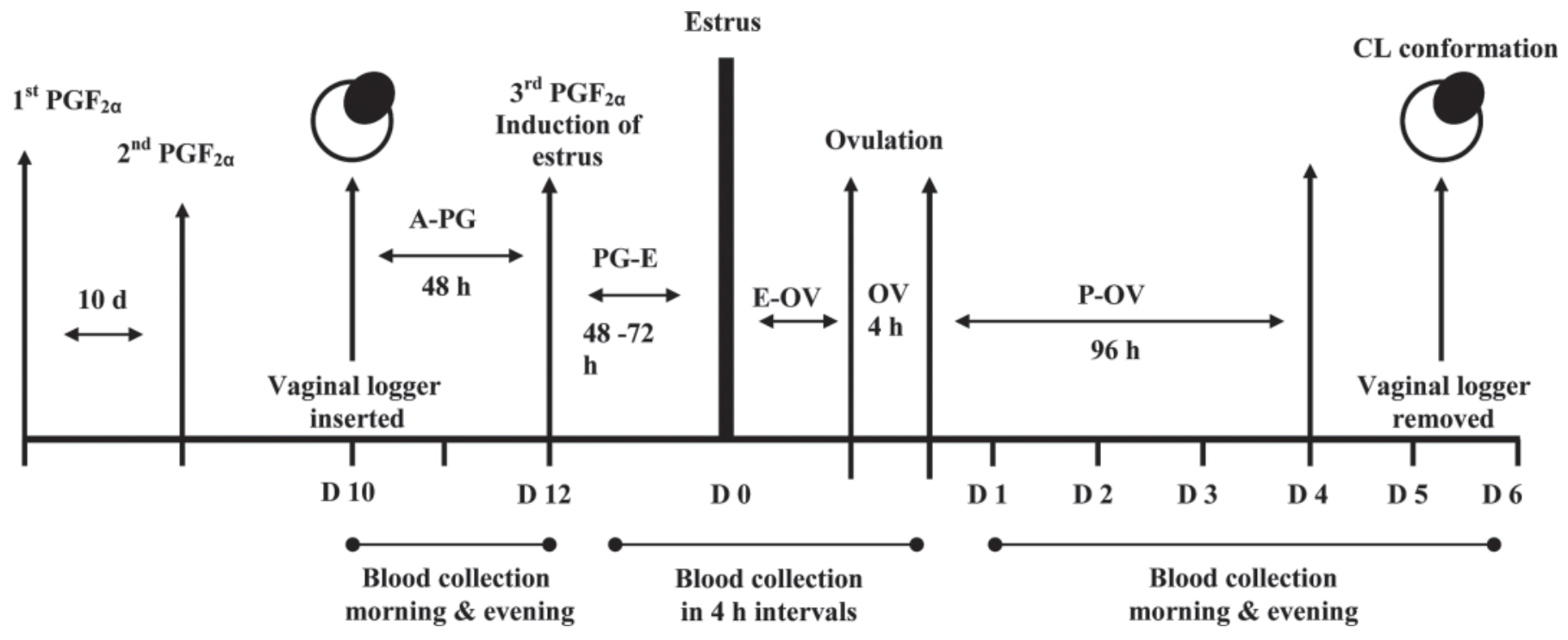

Figure 1. Experimental design considering 5 defined periods around induced estrus: $\mathrm{A}-\mathrm{PG}=48 \mathrm{~h}$ preceding the third $\mathrm{PGF}{ }_{2 \alpha}$ injection; $\mathrm{PG}-\mathrm{E}=$ from the third $\mathrm{PGF}_{2 \alpha}$ injection to the first sign of estrus; $\mathrm{E}-\mathrm{OV}=$ estrus to ovulation; $\mathrm{OV}=4 \mathrm{~h}$ around ovulation; $\mathrm{P}-\mathrm{OV}=96 \mathrm{~h}$ postovulation.

From d 11 to 12, blood samples were collected twice daily (0800 and $1800 \mathrm{~h}$ ). After the third $\mathrm{PGF}_{2 \alpha}$ injection, blood collection frequency was increased to $4-\mathrm{h}$ intervals $( \pm 1)$ until ovulation. After ovulation, blood samples were obtained twice daily again (0800 and 1800 h). Samples were centrifuged $(10 \mathrm{~min}, 1,000 \times g)$ and serum was stored in 2 aliquots at $-20^{\circ} \mathrm{C}$ until analysis. Serum P4 concentrations $(\mathrm{ng} / \mathrm{mL}$ ) were analyzed using a hormonal chemiluminescence assay (Immulite 2000, Siemens, Synlab, Berlin, Germany). The intra-and inter-assay coefficients of variation were 5.8 and $10.2 \%$, respectively.

\section{Statistical Analysis}

Data from temperature loggers were downloaded into Excel spreadsheets (Office 2003, Microsoft Deutschland GmbH, Munich, Germany) and analyzed using SPSS for Windows (Version 18.0, SPSS Inc., Munich, Germany). Hourly body temperature means were produced by averaging 12 temperature measures for the following 5 periods: 1) $48 \mathrm{~h}$ preceding the third $\mathrm{PGF}_{2 \alpha}$ injection (A-PG), 2) from the third $\mathrm{PGF}_{2 \alpha}$ injection to first signs of estrus (PG-E), 3) estrus to ovulation (E-OV), 4) a 4-h interval in which ovulation occurred (OV), and 5) a 96 -h post-ovulation period (P-OV). The hourly means were analyzed using one-way ANOVA in a completely randomized design to observe effects of induced estrus on body temperature. The repeated cycles $(\mathrm{n}=$ 5) from the same cows were considered independent due to the time interval between the 2 synchronization events $(44.0 \pm 8.6 \mathrm{~d})$. The effect of THI on body temperature was evaluated for individual cows, considering the 5 periods using covariate function in univariate analysis and Pearson correlation. The Pearson correlation method was used to study the effect of $\mathrm{P} 4$ on body temperature and the association between daily body temperature rhythms of A-PG and P-OV.

\section{RESULTS AND DISCUSSION}

A total of 16 estrous cycles were synchronized using 9 Holstein-Friesian dairy cows. Five estrous cycles were excluded from analysis because of cystic ovarian disease $(\mathrm{n}=2)$, acute mastitis $(\mathrm{n}=1)$, and loss of a logger ( $\mathrm{n}$ $=2$ ). Furthermore, 2 cows were used 2 and 3 times, respectively, in this study. Due to variation in pattern of body temperature for each cycle, we have considered it as independent induced cycle.

\section{Body Temperature Rhythms and Temperature Humidity Index}

Daily ambient temperature averaged $19.0 \pm 1.2^{\circ} \mathrm{C}$ (mean $\pm \mathrm{SD}$ ) during the study. Overall, relevant relationships between hourly means of THI and vaginal temperatures of 11 cows during induced estrus from third $\mathrm{PGF}_{2 \alpha}$ did not exist $(\mathrm{r}=0.21 ; P=0.226)$. Stratified by period, associations between THI and vaginal temperature existed for A-PG $(\mathrm{r}=0.20 ; P=0.000)$ and P-OV ( $\mathrm{r}=0.15 ; P=0.000)$ were significant but practically marginal (Table 1 ). The absence of a rel- 


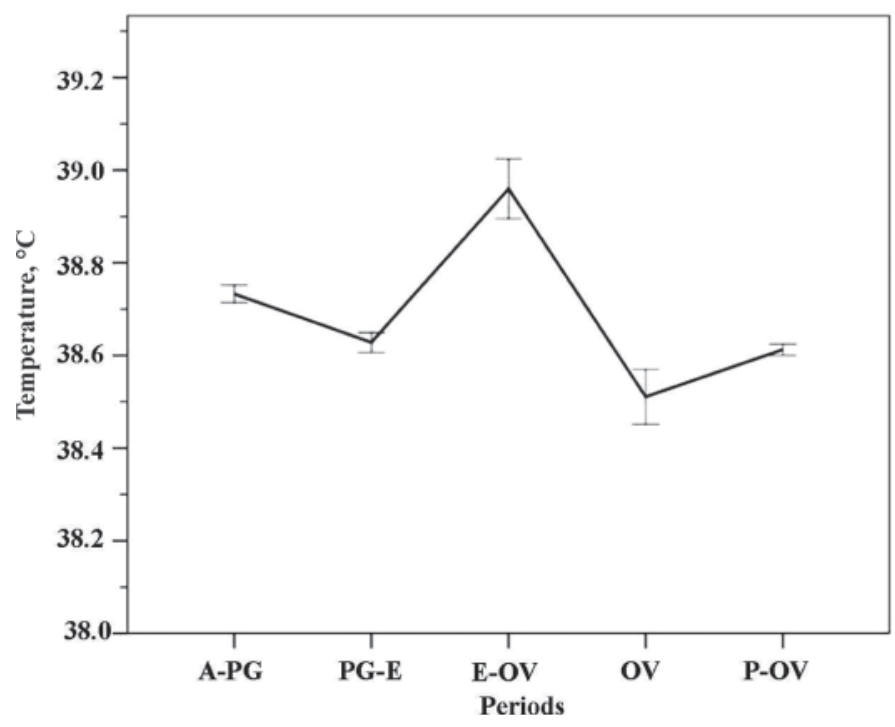

Figure 2. Hourly means $( \pm \mathrm{SE}$ ) of vaginal temperature for 11 induced estrus cycles from before $\mathrm{PGF}_{2 \alpha}$ administration to after ovulation. $\mathrm{A}-\mathrm{PG}=48 \mathrm{~h}$ preceding the third $\mathrm{PGF}_{2 \alpha}$ injection; $\mathrm{PG}-\mathrm{E}=$ from the third $\mathrm{PGF}_{2 \alpha}$ injection to the first sign of estrus; $\mathrm{E}-\mathrm{OV}=$ estrus to ovulation; $\mathrm{OV}=4 \mathrm{~h}$ around ovulation; $\mathrm{P}-\mathrm{OV}=96 \mathrm{~h}$ post-ovulation.

evant association between ambient and body temperature is indicative of relatively moderate environment conditions compared with other studies conducted in tropical climates (Kendall et al., 2006).

The concentration of serum $\mathrm{P} 4$ was $5.0 \pm 1.5 \mathrm{ng} / \mathrm{mL}$ $(\mathrm{n}=11)$ on d 10 during the A-PG period. Administration of $\mathrm{PGF}_{2 \alpha}$ on $\mathrm{d} 12$ regressed the CL and stimulated estrus within $50.7 \pm 16.9 \mathrm{~h}$. During estrus (E-OV), the $\mathrm{P} 4$ concentration averaged $0.3 \pm 0.1 \mathrm{ng} / \mathrm{mL}(P<0.01)$. The mean duration of estrus (E-OV) was $20.6 \pm 2.5 \mathrm{~h}$. The developing CL was diagnosed $114.9 \pm 3.8 \mathrm{~h}$ after ovulation (P-OV). At the same time, the serum $\mathrm{P} 4$ concentration had increased to $0.9 \pm 0.2 \mathrm{ng} / \mathrm{mL}$. The interval from $\mathrm{PGF}_{2 \alpha}$ injection to ovulation in our study $(71.0 \pm 7.6 \mathrm{~h})$ confirms previous reports on biparous $(83 \pm 4.4 \mathrm{~h} ; \mathrm{n}=4)$ and multiparous $(97 \pm 4.4 \mathrm{~h} ; \mathrm{n}=$ 4) cows (Swanson and Hafs, 1971; Christenson et al., 1975; Rajamahendran et al., 1989).

\section{Body Temperature Around Induced Estrus}

Highest body temperatures were observed during E-OV $\left(39.0 \pm 0.5^{\circ} \mathrm{C}\right)$ period, whereas lowest body temperatures were measured during the 4 -h period in which ovulation occurred $\left(38.5 \pm 0.2^{\circ} \mathrm{C}\right.$; Figure 2 ; Table $2 ; P$ $<0.05)$. During the $\mathrm{PG}-\mathrm{E}\left(38.6 \pm 0.3^{\circ} \mathrm{C}\right)$ period, body temperature was $0.1^{\circ} \mathrm{C}$ lower compared with the A-PG $\left(38.7 \pm 0.2^{\circ} \mathrm{C}\right)$ period $(P<0.05)$. It is speculative if this decrease was related to luteolysis and the decrease of serum P4 level, as suggested earlier (Wrenn et al., 1958; Kyle et al., 1998). Serum P4 concentrations were elevated for A-PG $(5.0 \pm 1.5 \mathrm{ng} / \mathrm{mL})$ and decreased for P-OV $(0.5 \pm 0.2 \mathrm{ng} / \mathrm{mL})$ period, respectively. A relationship, however, between body temperature and serum $\mathrm{P} 4$ concentrations $(\mathrm{n}=238$ matched pairs $)$ did not exist $(\mathrm{r}=0.018 ; P>0.05)$.

Although an elevated body temperature during estrus has been described earlier (Clapper et al., 1990; Mosher et al., 1990), the absolute increase during estrus in our data set (maximum of $0.5^{\circ} \mathrm{C}$ ) was considerably lower compared with Kyle et al. (1998) and Piccione et al. (2003) who reported an increase in body temperature of 0.9 to $1.3^{\circ} \mathrm{C}$. This discrepancy might be explained by the restriction of physical activity in the tie stall barn of our setup. Also, the calculation of the average temperature to which estrus temperature was compared differed between studies. This is the first study using 5 distinct periods to monitor and compare body temperatures during induced estrus. The above-mentioned authors had used a temperature increase of $0.3^{\circ} \mathrm{C}$ above a 4-d baseline as a definition of an estrus-related increase (Kyle et al., 1998) or analyzed the changes in temperature on $5 \mathrm{~d}$ preceding estrus (Piccione et al., 2003), respectively. These approaches might have biased the results.

In the past, the effect of induced ovulation and subsequent resetting of the hormonal cycle after $\mathrm{PGF}_{2 \alpha}$ has been discussed controversially. Two studies (Rajamahendran et al., 1989; Rajamahendran and Taylor, 1991) demonstrated a rise $\left(>1^{\circ} \mathrm{C}\right)$ in vaginal or rectal temperature after induced estrus, with measurements

Table 1. Correlation of paired measurements between temperature humidity index and temperature loggers inserted into the vagina of multiparous Holstein cows during 5 periods

\begin{tabular}{|c|c|c|c|}
\hline \multirow[b]{2}{*}{ Period } & \multirow[b]{2}{*}{$\begin{array}{c}\text { Paired } \\
\text { Observations, } \mathrm{n}\end{array}$} & \multicolumn{2}{|c|}{ Correlation } \\
\hline & & $\mathrm{r}$ & $P$-value \\
\hline $48 \mathrm{~h}$ preceding the third $\mathrm{PGF}_{2}$ injection & 528 & 0.20 & 0.000 \\
\hline From $\mathrm{PGF}_{2 \alpha}$ injection to first sign of estrus & 558 & 0.30 & 0.575 \\
\hline Estrus to ovulation & 226 & -0.19 & 0.234 \\
\hline $4 \mathrm{~h}$ around ovulation & 44 & -0.53 & 0.100 \\
\hline $96 \mathrm{~h}$ post-ovulation & 1,056 & 0.15 & 0.000 \\
\hline Overall & 2,412 & 0.21 & 0.226 \\
\hline
\end{tabular}


Table 2. Least significant differences of vaginal temperature, considering 5 periods relative to ovulation

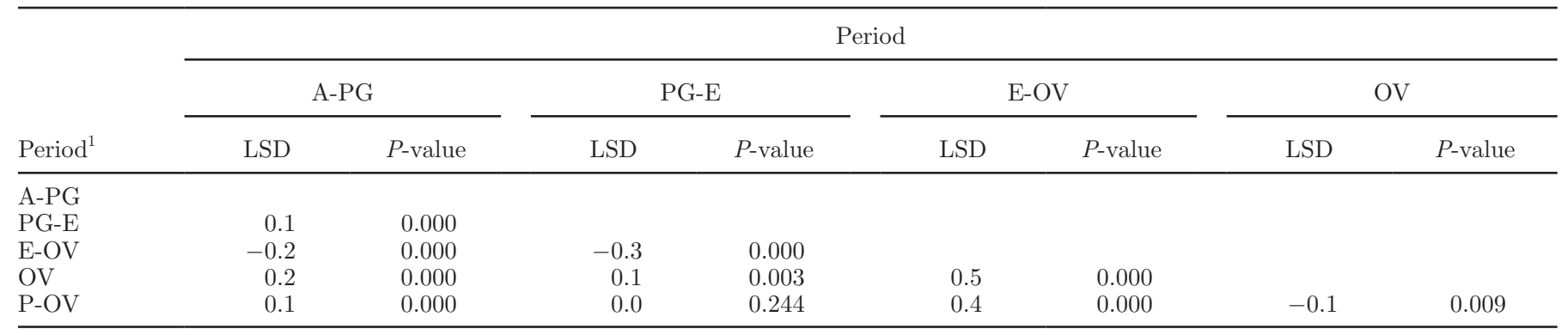

${ }^{1} \mathrm{~A}-\mathrm{PG}=48 \mathrm{~h}$ preceding the third $\mathrm{PGF}_{2 \alpha}$ injection; $\mathrm{PG}-\mathrm{E}=$ from the third $\mathrm{PGF}_{2 \alpha}$ injection to the first sign of estrus; E-OV = estrus to ovulation; $\mathrm{OV}=4 \mathrm{~h}$ around ovulation; $\mathrm{P}-\mathrm{OV}=96 \mathrm{~h}$ post-ovulation.

taken with clinical thermometers and in 4-h intervals. Only one study (Zartman et al., 1983) described more frequent monitoring of body temperature using intravaginal radio-telemetry transmitters in the $\mathrm{PGF}_{2 \alpha^{-}}$ induced 4 Holstein heifers, but failed to demonstrate an estrus-related increase in body temperature. Our data, based on vaginal temperature measured every 5 min, provide further evidence that body temperature is elevated during induced estrus.

It is not known if the rise in vaginal temperature during estrus is a consequence of the central thermoregulation being influenced by factors that regulate gonadotropinreleasing hormone or caused by the increased activity of the animal at the time of estrus, as suggested by Walton and King (1986). In our experiment, cows were housed in tie stalls during the whole observation period and, thus, restricted in their ability to move. This indicates that increased activity might not be the only factor that is responsible for the increase in body temperature at estrus. It has been demonstrated that the increase in vaginal temperature corresponds to the time of the preovulatory LH surge and the onset of estrus, which preceded ovulation by $24 \mathrm{~h}$ (Rajamahendran et al., 1989; Mosher et al., 1990). Also, the increased thermal conductivity of the vagina on the day before estrus due to increased vaginal blood flow (Abrams et al., 1973) may play a role in the temperature peak in studies using temperature loggers inserted into the vagina.

The thermogenic effect of $\mathrm{P} 4$ has been well established in humans (Czaja and Butera, 1986) and in whales (Katsumata et al., 2006). In the present study, vaginal temperature was slightly elevated $\left(38.7 \pm 0.2^{\circ} \mathrm{C}\right)$ during the luteal $(\mathrm{A}-\mathrm{PG})$ and lowered $\left(38.6 \pm 0.2^{\circ} \mathrm{C}\right)$ during the post-ovulatory (P-OV) phases, respectively. This observation corresponds to the high and low serum P4 concentrations. A correlation, however, between body temperature and $\mathrm{P} 4$ did not exist. These results were in accordance with previous reports (Lammoglia et al., 1997; Kyle et al., 1998). Similar differences between the luteal and post-ovulatory phase have been dem- onstrated by manually measuring vaginal temperature twice daily (Lewis and Newman, 1984) or using temperature radiotelemetry (Mosher et al., 1990; Redden et al., 1993) in cycling dairy heifers and postpartum cows. We speculate that the rise in body temperature during the luteal phase was caused by the increased P4 concentration. The mechanism, however, by which $\mathrm{P} 4$ causes the temperature to increase, is not understood at the present time.

Our data demonstrate that body temperature was lower around ovulation and confirm earlier findings of both cows and women that body temperature decreases before ovulation and increases after ovulation (Wrenn et al., 1958; Martinez et al., 1992).

Coefficient of correlation of body temperature measured between A-PG and P-OV periods was 0.64 $(P<0.001)$. During A-PG, the average temperature was $0.1^{\circ} \mathrm{C}$ higher compared with the $\mathrm{P}-\mathrm{OV}$ period $(P$ $<0.05)$. Highest hourly means of body temperature were observed around $1700 \mathrm{~h}\left(38.9 \pm 0.3^{\circ} \mathrm{C}\right)$ and 0800 $\mathrm{h}\left(38.7 \pm 0.1^{\circ} \mathrm{C}\right)$ for $\mathrm{A}-\mathrm{PG}$ and $\mathrm{P}-\mathrm{OV}$ periods, respectively. Lowest hourly means of body temperature were observed at $0500 \mathrm{~h}\left(38\right.$. Five $\left.\pm 0.1^{\circ} \mathrm{C}\right)$ and $0300 \mathrm{~h}(38.6$ $\pm 0.2^{\circ} \mathrm{C}$ ) for $\mathrm{A}-\mathrm{PG}$ and $\mathrm{P}-\mathrm{OV}$ periods, respectively. The diurnal rhythm observed was consistent with earlier reports (Bitman et al., 1984). Several factors have been shown to influence the time of daily maximum and minimum temperature, such as ambient conditions, housing, milking, and season (Kendall and Webster, 2009; Schütz et al., 2009).

\section{CONCLUSIONS}

Similar body temperature rhythms were observed before and after induced estrus. During induced estrous cycles, body temperature showed 2 troughs before and after estrus. We demonstrated that cows housed in a tie stall showed higher body temperature during induced estrus, although their ability to move was restricted. We hypothesize that not only higher activity during 
estrus is responsible for the increase in vaginal temperature but also other factors (e.g., increased vaginal blood flow) might contribute to this phenomenon.

\section{ACKNOWLEDGMENTS}

We thank the staff of the Clinic of Animal Reproduction, Freie Universität Berlin, Germany, who provided great care for the animals. We also acknowledge the financial support given to Vishal Suthar by the European Commission under Erasmus Mundus External Cooperation Window Lot 15 for conducting this work as part of his $\mathrm{PhD}$ dissertation.

\section{REFERENCES}

Abrams, R. M., W. W. Thatcher, F. W. Bazer, and C. J. Wilcox. 1973. Effect of estradiol-17 $\beta$ on vaginal thermal conductance in cattle. J. Dairy Sci. 56:1058-1062.

Bewley, J. M., M. E. Einstein, M. W. Grott, and M. M. Schutz. 2008. Comparison of reticular and rectal core body temperatures in lactating dairy cows. J. Dairy Sci. 91:4661-4672.

Bitman, J., A. Lefcourt, D. L. Wood, and B. Stroud. 1984. Circadian and ultradian temperature rhythms of lactating dairy cows. J. Dairy Sci. 67:1014-1023.

Brown-Brandl, T. M., R. A. Eigenberg, J. A. Nienaber, and G. L. Hahn. 2005. Dynamic response indicators of heat stress in shaded and non-shaded feedlot cattle, part 1: Analyses of indicators. Biosystems Eng. 90:451-462.

Christenson, R. K., S. E. Echternkamp, and D. B. Laster. 1975. Oestrus, LH, ovulation and fertility in beef heifers. J. Reprod. Fertil. 43:543-546.

Clapper, J. A., J. S. Ottobre, A. C. Ottobre, and D. L. Zartman. 1990. Estrual rise in body temperature in the bovine I. Temporal relationships with serum patterns of reproductive hormones. Anim. Reprod. Sci. 23:89-98.

Czaja, J. A., and P. C. Butera. 1986. Body temperature and temperature gradients: Changes during the estrous cycle and in response to ovarian steroids. Physiol. Behav. 36:591-596.

Ipema, A. H., D. Goense, P. H. Hogewerf, H. W. J. Houwers, and H. van Roest. 2008. Pilot study to monitor body temperature of dairy cows with a rumen bolus. Comput. Electron. Agric. 64:49-52.

Katsumata, E., S. Jaroenporn, H. Katsumata, S. Konno, Y. Maeda, G. Watanabe, and K. Taya. 2006. Body temperature and circulating progesterone levels before and after parturition in killer whales (Orcinus orca). J. Reprod. Dev. 52:65-71.

Kendall, P. E., P. P. Nielsen, J. R. Webster, G. A. Verkerk, R. P. Littlejohn, and L. R. Matthews. 2006. The effects of providing shade to lactating dairy cows in a temperate climate. Livest. Sci. 103:148-157.

Kendall, P. E., C. B. Tucker, D. E. Dalley, D. A. Clark, and J. R. Webster. 2008. Milking frequency affects the circadian body temperature rhythm in dairy cows. Livest. Sci. 117:130-138.

Kendall, P. E., and J. R. Webster. 2009. Season and physiological status affects the circadian body temperature rhythm of dairy cows. Livest. Sci. 125:155-160.
Kyle, B. L., A. D. Kennedy, and J. A. Small. 1998. Measurement of vaginal temperature by radiotelemetry for the prediction of estrus in beef cows. Theriogenology 49:1437-1449.

Lammoglia, M. A., R. A. Bellows, R. E. Short, S. E. Bellows, E. G. Bighorn, J. S. Stevenson, and R. D. Randel. 1997. Body temperature and endocrine interactions before and after calving in beef cows. J. Anim. Sci. 75:2526-2534.

Lefcourt, A. M., J. B. Huntington, R. M. Akers, D. L. Wood, and J. Bitman. 1999. Circadian and ultradian rhythms of body temperature and peripheral concentrations of insulin and nitrogen in lactating dairy cows. Domest. Anim. Endocrinol. 16:41-55.

Lewis, G. S., and S. K. Newman. 1984. Changes throughout estrous cycles of variables that might indicate estrus in dairy cows. J. Dairy Sci. 67:146-152.

Martinez, A. R., M. H. A. van Hooff, E. Schoute, M. van der Meer, F. J. M. Broekmans, and P. G. A. Hompes. 1992. The reliability, acceptability and applications of basal body temperature (BBT) records in the diagnosis and treatment of infertility. Eur. J. Obstet. Gynecol. Reprod. Biol. 47:121-127.

Mosher, M. D., J. S. Ottobre, G. K. Haibel, and D. L. Zartman. 1990. Estrual rise in body temperature in the bovine II. The temporal relationship with ovulation. Anim. Reprod. Sci. 23:99-107.

Piccione, G., G. Caola, and R. Refinetti. 2003. Daily and estrous rhythmicity of body temperature in domestic cattle. BMC Phys. 3:7. Accessed July 9, 2010. http://www.biomedcentral.com/1472$6793 / 3 / 7$.

Rajamahendran, R., J. Robinson, S. Desbottes, and J. S. Walton. 1989. Temporal relationships among estrus, body temperature, milk yield, progesterone and luteinizing hormone levels, and ovulation in dairy cows. Theriogenology 31:1173-1182.

Rajamahendran, R., and C. Taylor. 1991. Follicular dynamics and temporal relationships among body temperature, oestrus, the surge of luteinizing hormone and ovulation in Holstein heifers treated with norgestomet. J. Reprod. Fertil. 92:461-467.

Redden, K. D., A. D. Kennedy, J. R. Ingalls, and T. L. Gilson. 1993. Detection of estrus by radiotelemetric monitoring of vaginal and ear skin temperature and pedometer measurements of activity. J. Dairy Sci. 76:713-721.

Schütz, K. E., A. R. Rogers, N. R. Cox, and C. B. Tucker. 2009. Dairy cows prefer shade that offers greater protection against solar radiation in summer: Shade use, behaviour, and body temperature. Appl. Anim. Behav. Sci. 116:28-34.

Swanson, L. V., and H. D. Hafs. 1971. LH and prolactin in blood serum from estrus to ovulation in Holstein heifers. J. Anim. Sci. $33: 1038-1041$

Tucker, C. B., A. R. Rogers, and K. E. Schütz. 2008. Effect of solar radiation on dairy cattle behaviour, use of shade and body temperature in a pasture-based system. Appl. Anim. Behav. Sci. 109:141-154.

Vickers, L. A., O. Burfeind, M. A. G. von Keyserlingk, D. M. Veira, D. M. Weary, and W. Heuwieser. 2010. Technical note: Comparison of rectal and vaginal temperatures in dairy cows. J. Dairy Sci. 93:5246-5251.

Walton, J. S., and G. J. King. 1986. Indicators of estrus in Holstein cows housed in tie stalls. J. Dairy Sci. 69:2966-2973.

Wrenn, T. R., J. Bitman, and J. F. Sykes. 1958. Body temperature variations in dairy cattle during the estrous cycle and pregnancy. J. Dairy Sci. 41:1071-1076.

Zartman, D. L., D. M. Hallford, L. A. Tierney, and M. Y. Hussain. 1983. Reproductive characteristics of Holstein heifers fitted with intravaginal temperature transmitters. Theriogenology 19:541554 . 